\title{
The Dependency Game and Potential Gains in Energy Sector of Eurasia
}

\author{
Yeşim Reel, Marmara University
}

\begin{abstract}
The integration of the Eurasian super-continent will potentially have major implications for the Eurasian region, and also for the world economy.

Traditionally, economic integration has ben analyzed and measured mostly with regard to trade and transport linkages. Turning from the most obvious linkages in energy to other areas, the first point to be made is that the collapse of the Former Soviet Union (FSU) had a devastating impact on trade within the former Soviet regional trading bloc known as COMECON (Linn and Tiomkin,2007).

Opening Greater Central Asia to continental trade in energy and goods would give countries in the region greater access to foreign technology and foreign exchange revenue, increase market access. Forecasts about the positive effects of construction and restoration of road corridors suggest there could be enormous gains (Norling and Swanström,2007).

Moreover, potential gains in energy transit are also massive (Pandian,2005).

It is stated that the increasing demand for Eurasian energy is creating a very interesting dependency game involving three groups of countries. The existing dependencies are based on a number of variables (Svedberg,2007).

The aim of this paper is to analyze the current situation, the dependency game and potential gains in Eurasia's energy sector. The current situation's analysis presents a framework which shows Eurasia's energy sector's data, trends and problems. The dependency game indicates the linkages between different countries which are related to the sector, and these countries' positions. The potential gains are important particularly in energy production, energy projects and energy trade for Eursia. Considering all these, first part presents introduction. The second part analyzes the current situation, the dependency game and, gives outcomes of this dependency in the sector. Third part presents the potential gains for this sector. Last part gives a conclusion.
\end{abstract}

JELCodes: Q4

\section{Introduction}

It is stated that the integration of the Eurasian super-continent will potentially have major implications for the Eurasian region, and also for the world economy (Linn and Tiomkin, 2007). Remarkable opportunities have opened on the Eurasian continent. Not only will Greater Central Asia benefit from this, but India, Pakistan, Iran, China, Azerbaijan, and Russia have similar gains to make by engaging the region, including energy.

Opening Greater Central Asia to continental trade in energy and goods would give countries in the region greater access to foreign technology and foreign exchange revenue, increase market access (Norling and Swanström, 2007).

Moreover, potential gains in energy transit are also massive. Whether India's and Pakistan's energy needs are met by building the Turkmenistan-Afghanistan-Pakistan-India pipeline across Afghanistan or the Iran-India-Pakistan pipeline, transit states will benefit substantially. For example, it has been estimated that Pakistan would gain a total of $\$ 14$ billion in 30 years from building the Indo-Iran pipeline (Pandian, 2005).

It is argued that the increasing demand for Eurasian energy is creating a very interesting dependency game involving three groups of countries. The existing dependencies are based on a number of variables (Svedberg, 2007). Therefore it is important to analysis energy sector in 
Eurasia. In order to anaysis the sector, firstly, it is summarized and analyzed the current situation and the dependency game. Secondly it is given the potential gains for this sector. In the end, it is given a conclusion.

\section{The Current Situation and Dependency Game}

\subsection{The Current Situation}

While the breakup of the Soviet Union created a number of different, new stakeholders in pieces of the energy supply system, and a number of formally independent producing states. In particular, almost all Central Asian and Caucasian natural gas (and oil) had to initially pass through the Russian pipeline network to reach foreign customers. Thus Russia, through Gazprom, remained the monopoly supplier of Eurasian gas to Europe.

This situation remained essentially unchanged until the Russian financial collapse of 1998, and the subsequent economic recovery driven by a dramatic rise in oil, and other energy, prices. That crisis brought a change in the government of Russia, and ushered in a new era of rising energy demand and prices.

The Russian state tightened its control over oil and natural gas supplies to the rest of the world, reinforcing its monopoly over oil (Transneft') and gas (Gazprom) export pipelines. In the light of these developments, the European Union has initiated efforts to form a common energy policy and seek ways to diversify energy — and in particular natural gas — supplies. And Russia began looking to develop alternate export routes to lucrative European markets. Thus a complex and changing structure of interdependence has arisen (Ericson,2009).

Based on this knowledge and, also International Energy Annual is considered, it is realized that specially four Eurasian countries, which are Russia, Azerbaijan, Kazakhstan and Ukraine, have crucial role in the region.

Russia holds the world's largest natural gas reserves, the second largest coal reserves, and the eighth largest oil reserves. Russia is also the world's largest exporter of natural gas, the second largest oil exporter and the third largest energy consumer. Russia is a major world oil producer, sometimes producing even more than Saudi Arabia (IEA, 2010).

Azerbaijan is emerging as an important exporter of oil and natural gas and as a transport corridor between Europe and Central Asia. Its strategic location bordering the Caspian Sea has attracted significant international interest in developing its oil and natural gas reserves. Oil production in Azerbaijan more than quadrupled between 1997 and 2008 to 875,000 bbl/d and is expected to increase further. With the startup of the Shah Deniz natural gas and condensate field in 2007, Azerbaijan went from being a net natural gas importer to a net exporter, shipping increasing amounts of natural gas via Turkey to Europe.

Kazakhstan has the second largest oil reserves among the former Soviet republics after Russia as well as the second largest oil production. The country also has large reserves of natural gas and steadily increasing production. With large amounts of associated natural gas at its oil fields, Kazakhstan has the potential to become a net exporter in upcoming years (IEA, 2010).

Table 1, Table 2, Table 3, Table 4 and Table 5 show more detailed information about Azerbaijan, Kazakhstan and Russia on energy data (IEA, 2010).

\begin{tabular}{|c|c|c|c|c|c|}
\hline $\begin{array}{c}\text { Petroleum } \\
\text { (Thousand barrels per day) }\end{array}$ & Azerbaijan & Russia & Kazakhstan & Eurasia & World \\
\hline Total Oil Production & 874.98 & $9,792.33$ & $1,429.95$ & 12,527 & 85,429 \\
\hline Crude Oil Production & 869.56 & $9,356.78$ & $1,345.42$ & 11,927 & 73,652 \\
\hline Consumption & 121.00 & $2,916.00$ & 244.00 & 4,350 & 85,752 \\
\hline Net Export/Imports & 753.98 & $6,876.33$ & $1,185.95$ & 8,177 & -- \\
\hline
\end{tabular}




\begin{tabular}{|c|c|c|c|c|c|}
\hline Total Oil Export to US & 74 & 465 & 12 & 605 & 12,915 \\
\hline Refinery Capacity & 399 & 5,428 & 345 & 8,205 & 85,460 \\
\hline $\begin{array}{c}\text { Proved Reserves(billion } \\
\text { barrels) }\end{array}$ & 7.00 & 60.00 & 30.00 & 99 & 1,332 \\
\hline
\end{tabular}

Table 1. Petroleum Data belongs to Azerbaijan, Russia, Kazakhstan,Eurasia and World in 2008

\begin{tabular}{|c|c|c|c|c|c|}
\hline $\begin{array}{c}\text { Natural Gas } \\
\text { (Billion Cubic Feet) }\end{array}$ & Azerbaijan & Russia & Kazakhstan & Eurasia & World \\
\hline Production & 572 & 23,386 & 398 & 29,939 & 109,789 \\
\hline Consumption & 376 & 16,799 & 409 & 24,318 & 110,262 \\
\hline Net Export/Imports(-) & 196 & 6,586 & -10 & 5,586 & -- \\
\hline $\begin{array}{c}\text { Proved Reserves } \\
\text { (Trillion Cubic Feet) }\end{array}$ & 30 & 1,680 & 100 & 2,015 & 6,212 \\
\hline
\end{tabular}

Table 2. Natural Gas Data belongs to Azerbaijan, Russia, Kazakhstan,Eurasia and World in 2008

\begin{tabular}{|c|c|c|c|c|c|}
\hline $\begin{array}{c}\text { Electricity } \\
\text { (Billion Kilowatthours) }\end{array}$ & Azerbaijan & Russia & Kazakhstan & Eurasia & World \\
\hline Net Generation & 21.95 & 939.41 & 67.75 & 1,376 & 18,010 \\
\hline Net Consumption & 19.67 & 816.01 & 61.80 & 1,193 & 16,385 \\
\hline Installed Capacity (GWe) & 5.21 & 220.91 & 18.73 & 348 & 4,267 \\
\hline
\end{tabular}

Table 3. Electricity Data belongs to Azerbaijan, Russia, Kazakhstan,Eurasia and World in 2006

\begin{tabular}{|c|c|c|c|c|c|}
\hline $\begin{array}{c}\text { Total Primary Energy } \\
\text { (Quadrillion Btu) }\end{array}$ & Azerbaijan & Russia & Kazakhstan & Eurasia & World \\
\hline Production & 1.659 & 53.133 & 5.711 & 70 & 468 \\
\hline Consumption & 0.702 & 30.298 & 2.971 & 46 & 472 \\
\hline $\begin{array}{c}\text { Energy Intensity } \\
\text { Consumption per dollar of } \\
\text { gross domestic product } \\
\text { using purchasing power } \\
\text { parities. } \\
\text { (Btu per 2005 U.S. } \\
\text { Dollars) }\end{array}$ & 13,595 & 16,522 & 20,368 & 17,328 & 7,811 \\
\hline
\end{tabular}

Table 4. Total Primary Data belongs to Azerbaijan, Russia, Kazakhstan,Eurasia and World in 2006

\begin{tabular}{|c|c|c|c|c|c|}
\hline $\begin{array}{c}\text { Coal } \\
\text { (Million Short Tons) }\end{array}$ & Azerbaijan & Russia & Kazakhstan & Eurasia & World \\
\hline Production & 0.000 & 318.591 & 107.838 & 514 & 7,047 \\
\hline Consumption & 0.000 & 230.402 & 77.453 & 410 & 7,019 \\
\hline Net Export/Imports(-) & 0.000 & 85.908 & 31.332 & 103 & -- \\
\hline
\end{tabular}

Table 5. Total Primary Data belongs to Azerbaijan, Russia, Kazakhstan,Eurasia and World in 2007

Ukraine is important to world energy markets because it is a critical transit center for exports of Russian oil and natural gas to Europe, as well as a significant energy consumer. Ukraine's 
gas sector has been dominated by Naftogaz. Ukraine has the seventh-largest amount of coal resources in the world, but underinvestment, and a lack of progress on deregulation have made the country a net coal importer. Ukraine has sufficient generating capacity to supply more than twice its electricity needs, but the country's ageing infrastructure is in need of investment and maintenance (Heifetz, 2009,IMF,2007).

Followings are stated as energy trends in Eurasia:

1)Slow expansion of European and Japanese demand

2)Rapid expansion of import demand in China, India; recovery from depressed levels in FSU

3) Gas demand growing more rapidly than oil demand

4) Rapid growth in electricity demand

5) Rapid expansion of FSU energy exports in recent years, but now slowing down

6) Russia is the main factor on the supply side (Linn and Tiomkin,2008).

EurAsEC (Eurasian Economic Community) countries desperately need investments, because of possesing vast resources. Specially, Russian investments have been made in the energy sector and infrastructure in EurAsEC countries. Some oil and gas production projects are closely associated with joint reconstruction of existing pipelines or construction of new ones for exporting fuel and raw materials. One of the most active Russian players in EurAsEC is LUKoil. It has participated in eleven oil projects in Kazakhstan since 1995, when a contract for the development of the northern part of Kumkol was made. Since that time LUKoil has invested in Kazakhstan's economy over $\$ 4.5$ billion (Heifetz, 2009).

On the other hand, it is stated that the investment cooperation of Russia and other EurAsEC countries encounters a number of problems; the most important of them are given below (Heifetz, 2009):

1. Political opposition to investment expansion.

2. Lack of flexibility in Russian company policy.

3. Increasing competition.

4. There was no progress in multilateral cooperation.

5. Governmental support for the investment expansion of Russian companies and investment cooperation in EurAsEC is inadequate.

Formulation of a common policy for EurAsEC countries towards the use of energy resources and transport services and cooperation in this area are priority economic goals for EurAsEC (Heifetz, 2009). But problems, which are mentioned above, could create important obstacles for the use of energy sources and others.

\subsection{The Dependency Game}

According to Swedberg, the increasing demand for Eurasian energy is creating a very interesting dependency game involving three groups of countries. The countries of the European Union (EU) are dependent on oil and gas from countries in the Commonwealth of Independent States (CIS) for consumption, whereas the CIS countries in general and Russia in particular are dependent on the EU countries for exports. Both the CIS and EU countries are dependent on the Baltic States, Belarus, Ukraine, and Poland for transiting energy from the former to the latter. The transit countries, for their part, are dependent on CIS energy both for domestic consumption and as a source of revenue, as the transit traffic contributes significant shares of their gross domestic product (Svedberg, 2007).

It is believed that this is a game where there must be winners on one side (producers) and losers (consumers) on the other, but it is better understood as a complicated interdependency game where some countries suffer more than others.

Under these conditions, while the introduction and diffusion of energy-saving policies may help, they are unlikely to relieve the upward pressure on prices. Consequently, all actors should 
be concerned about policies that would support and guarantee the flow of supply. While this entails, in the short term, growing general concern for investments in existing and new oilfields and transport infrastructure for energy (oil and gas primarily), there are also pressures for diversifying energy dependence over the longer term. The advantage of high energy prices, on the other hand, gives a leverage to energy producers that they may wish to use against consumers in other areas when there is a conflict of interest (Malle, 2007).

Moreover it is noted that the energy trade in Eurasia is not a zero-sum game but rather an interesting example of regional interdependence. European countries on average import about 43 percent of their total oil and gas consumption. Some countries are more dependent than others. Most of the Central and Eastern European countries are fully dependent on CIS imports for their oil consumption as they have no or very little own production and limited alternative import routes.

The transit countries in between Western Europe and Russia - most notably the Baltic States, Poland,Ukraine, and Belarus - play a crucial role in the dependency game. They are today among the most dependent on Russian energy imports for consumption and revenues and are, at the same time, the energy bridge between Europe and Russia. As much as 80 percent of Russian gas exports are transited through Ukraine and 25 percent of its crude oil exports.

The existing dependencies could be based on a number of variables that are very difficult to fully assess. Most analysts seem to agree that demand will remain high and growing, especially as the demand in the large emerging markets, most notably China, is increasing rapidly. The underlying issues are related to the future supply, infrastructure, and price of oil and gas (Svedberg, 2007).

Swedberg stated that Russia needs Europe for exports and investments. It is therefore more important than ever that Russia and the EU get their act together and agree on a joint energy policy based on mutual dependency. One of the most interesting outcomes of this dependency game is what role the transit countries will play, both in shaping the policy and as future energy bridges (Svedberg, 2007).

Morelli suggested that Russia, with its vast resources, especially gas, will likely continue to be Europe's primary supplier of gas for the indefinite future. For Europe, trying to construct an overall common energy policy with a common external energy strategy, directed especially at Russia, could be critical. Europe's understanding of Russia's dependence on Europe as a stable customer for Russia's energy resources and an eager investor in Russia's economy presents the EU with several options regarding its energy relations with Russia (Morelli, 2006).

\section{The Potential Gains}

Opening Greater Central Asia to continental trade in energy and goods would give countries in the region greater access to foreign technology and foreign exchange revenue, increase market access, and reduce the harmful effects of being landlocked. Forecasts about the positive effects of construction and restoration of road corridors suggest there could be enormous gains (Norling and Swanström, 2007).

Potential gains in energy transit are also massive. Whether India's and Pakistan's energy needs are met by building the Turkmenistan-Afghanistan-Pakistan-India pipeline across Afghanistan or the Iran-India-Pakistan pipeline, transit states will benefit substantially. For example, it has been estimated that Pakistan would gain a total of $\$ 14$ billion in 30 years from building the Indo-Iran pipeline (Pandian, 2005).

Supporting energy projects in the region and regional energy integration promises to have huge potential long-term payoffs; the BTC pipeline is a case in point. The pipeline was feasible because of financial and political backing from the United States and Europe in a project most observers had doomed beforehand. This pipeline not only relieved Azerbaijan from dependence on Russia, but its construction also signified a long-term commitment from the West to 
Azerbaijan's future.

In order to make full use of the potentials that have opened on the Eurasian continent, there is a need to strengthen cooperative mechanisms and make sizable efforts in restoring infrastructure and reducing border inefficiency. The scope of activity cannot be limited to Central Asia alone. Greater Central Asia has equal complementarity with the economies of South Asia and East Asia as with Russia and Europe (Norling and Swanström, 2007).

Klaassen,et al. show on different scenarios about the prospects for Eurasia. According to them, the prospects for Eurasia are ultimately determined by GDP increases, energy intensity changes, technology dynamics and resource availability. Energy demand projections assume that the next decades are characterized by successful reform and restructuring in Eurasia as a whole, leading to sustained investments in the energy sector and economic development that is reflected in the long-term improvement of energy intensities.

Between 1990 and 2050 electricity demand in Eurasia is expected to increase by a factor of five in Asia and by nearly a factor of three in the European part (FSU, EEU and WEU). The challenge therefore is to match the rich energy resources of Eurasia to growing demands. Resources and demands must be matched geographically through trade, transportation networks and energy grids (Klaassen,et al.,1999).

\section{Conclusion}

It is suggested that continental trade in energy and goods would give countries in Eurasia greater access to foreign technology and foreign exchange revenue, increase market access, and reduce the harmful effects of being landlocked.

Since the region possesses vast resources, and EurAsEC countries desperately need investments. Specially, Russian investments have been made in the energy sector and infrastructure in EurAsEC countries. Some oil and gas production projects are closely associated with joint reconstruction of existing pipelines or construction of new ones for exporting fuel and raw materials. Formulation of a common policy for EurAsEC countries towards the use of energy resources and transport services and cooperation in this area are priority economic goals for EurAsEC.

Moreover, it is stated that the increasing demand for Eurasian energy is creating a very interesting dependency game. The existing dependencies between different countries' groups could be based on a number of variables that are very difficult to fully assess. Most analysts seem to agree that demand will remain high and growing, especially as the demand in the large emerging markets. Therefore, Eurasia could have advantage, using linkages and dependency game.

In order to make full use of the potentials that have opened on the Eurasian continent, there is a need to strengthen cooperative mechanisms and make sizable efforts in restoring infrastructure and reducing border inefficiency. For all these, strong and efficient relation should be maintain and, also comprehensive and efficient projects are necessary.

\section{References}

- Ericson, 2009. "Eurasian Natural Gas Pipelines: The Political Economy of Network Interdependence", Eurasian Geography and Economics, 2009, 50, No. 1, p.32, 33.

- Heifetz, 2009 "Russian Direct Investments in EurAsEC and Their Role in Energy and Transport Infrastructure Development in Eurasia", EDB Eurasian Integration Yearbook 2009,www.eabr.org/eng/publications/IntegrationYearbook/index.wbp? article-id= F591B688-BF0D-45FC-9EFD-B31E0E1E4DD7(03.08.2010).

- IEA,2010, International Energy Annual, http://www.eia.doe.gov/country_energy_data.cfm?fibs=AJ (05.08.2010). 
- International Monetary Fund (IMF), 2007. Ukraine: Selected Issues, IMF Country Report No. 07/47, Washington, p.20.

- Klaassen et al.,1999. Towards New Energy Infrastructures in Eurasia: a background paper, Interim Report IR-99-17, December, p.6, 8.

- Linn, and Tiomkin, 2007. Economic Integration of Eurasia- Opportunities and Challenges of Global Significance, Edited by Anders Aslund and Marek Dabrowski, Europe After Enlargement, Cambridge University Press, Cambridge.

- Linn, Johannes and Tiomkin, 2008. "Economic Integration of Eurasia: Opportunities and Challenges of Global Significance", Asia Europe Journal Volume 4 Number 1 April 23 February, p.16.

- Malle, 2007. "Energy and Central Asia: an Overview of Current Issues", Transition Studies Review, 14, p.149,150.

- Morelli, 2006. “The European Union's Energy Security Challenges”, in Congressional Research Service Report for Congress September 11, 2006, Washington, p.12.

- Norling and Swanström, 2007. "The Virtues and Potential Gains of Continental Trade in Eurasia", Asian Survey, 47, p. 351,352, 369. 370-372.

- Pandian,2005. "Energy Trade as a Confidence Building Measure between India and Pakistan: A Study of the Indo-Iran Pipeline Project," Contemporary South Asia 14:3, September, p.314.

- Svedberg, 2007. "Energy in Eurasia: the Dependency Game”,Transition Studies Review, 14 (1): p.195,197, 201. 